\title{
Analisis Tokoh pada Cerpen "Ibu Pergi Ke Laut" Melalui Pendekatan Kritik Mimetik Serta Relevansinya dengan Pembelajaran Sastra Di Sekolah Dasar
}

\author{
Heny Kusuma Widyaningrum \\ PGSD FKIP Universitas PGRI Madiun \\ heny@unipma.ac.id
}

\begin{tabular}{ll}
\hline Informasi artikel & \\
\hline Sejarah artikel: & \\
Diterima & 30-II-2017 \\
Revisi & 3I-04-2018 \\
Dipublikasikan & Mei 2018
\end{tabular}
\begin{abstract}
ABSTRAK
Penelitian ini bertujuan untuk menganalisis kritik sastra melalui pendekatan mimetik pada cerpen Ibu Pergi ke Laut karya Puthut EA dan menjelaskan relevansinya dengan pembelajaran sastra di Sekolah Dasar (SD). Penelitian ini termasuk penelitian deskriptif kualitatif. Teknik pengumpulan data yang digunakan adalah teknik pustaka, simak, dan catat. Teknik analisis data yang digunakan adalah analisis data secara dialektik. Adapun novel Ibu Pergi ke Laut berdasarkan kisah nyata, yaitu musibah tsunami Aceh yang terjadi pada tanggal 26 Desember 2004. Banyak data yang mirip dengan data-data faktual yang dapat dibuktikan kebenarannya karena kisah tersebut merupakan kejadianbenar-benar terjadi dan cerminan nyata apa yang dialami baik oleh korban maupun kelurga yang ditinggalkan pada saat itu. Cerpen tersebut dapat dijadikan siswa sebagai bahan pembelajaran sastra di SD dari pengalaman orang lain untuk direfleksikan dalam mengahadapi masalah dalam kehidupan.
\end{abstract} Kata kunci:

Pendekatan kritik mimetik pembelajaran sastra

Key word:

mimetic approach criticism literature learning

\begin{abstract}
The objective of this study is to analyze the literary criticism through mimetic approach on short stories Ibu Pergi ke Laut by Puthut EA and explain the relevance with learning literature in Elementary school. This research is descriptive qualitative study. Data collection techniques used is book research, check out, and record. Data analysis technique used is the analysis of dialectical data. Novel Ibu Pergi ke Laut is based on the real story of tsunami in Aceh on December 26, 2004. Most of the data is similar to the data which the truth of the fact can be proved because the story is really happened and reflected the real experienced by either the victim or the family at that time. This short story can be used by the students as literature learning materials in primary schools which the story was taken from others' experience reflected how to face a problem in life.
\end{abstract}

\section{Copyright (C) 2018 Universitas Ahmad Dahlan. All Right Reserved}

\section{Pendahuluan}

Karya sastra merupakan hasil pikiran dan imajinasi yang bersifat indah dan dapat menimbulkan kesan positif bagi pembaca. Pengarang menulis karya sastra tidak hanya semata-mata hanya menimbulkan rasa keindahan melalui kata-kata, tetapi juga ingin menyampaikan pesan dan amanat kepada pembaca. Hal tersebut dipertegas melalui pendapat Moody (1971: 3) bahwa karya sastra bukan hanya bahasa yang dipakai untuk mengaplikasikannya, melainkan juga dianggap sebagai suatu pernyataan yang kompleks dan luas tentang penulis kepada pembacanya.
Karya satra dalam bentuk karya fiksi dapat dibedakan dalam beberapa bentuk, antara lain drama, dongeng, puisi novel, dan cerpen. Perbedaan berbagai macam bentuk pada dasarnya hanya terletak pada kompleksitas isi cerita, kadar panjang pendeknya atau alur cerita, dan jumlah tokoh dalam cerita. Aminuddin (2011:66) mengungkapkan bahwa elemen-elemen yang dikandung dalam karya fiksi atau cara pengarang memaparkan isi cerita mempunyai kesamaan walaupun dalam unsur-unsur tertentu terdapat perbedaan. Dengan demikian, hasil telaah suatu karya fiksi, salah satunya keterampilan telaah itu, dapat juga diterapkan baik dalam rangka 
menelaah cerpen. Rahayu (20I4: 46) menegaskan bahwa karya sastra, termasuk cerpen perlu dianalisis karena karya tersebut termasuk struktur yang kompleks, tanpa dianalisis karya sastra tidak dapat dimengerti leh pembaca dengan baik.

Salah satu telaah pada karya sastra berbentuk cerpen dapat berupa kritik sastra. Wellek (dalam Pradopo, 20II: I82) mengungkapan bahwa kritik sastra merupakan salah satu cabang studi sastra. Kritik sastra adalah hasil pertimbangan baik atau buruk dalam kesusastraan, alasan-alasan tentang isi dan bentuk hasil kesusastraan. Sebenarnya mengkritik karya sastra itu bukan hanya terbatas pada pertimbangan baik-buruknya saja, melainkan juga ada aktivitas lainnya yang sangat penting (Pradopo, 201 I:182).

Menurut Nurgiyantoro (2007:33I) sastra yang mengandung pesan kritik biasanya lahir di tengah masyarakat jika terjadi hal-hal yang kurang beres dalam kehidupan sosial dan masyarakat. Kritik sosial yang digambarkan dalam karya sastra merupakan hubungan konkrit antara karya sastra dengan masyarakat. Kritik sosial dalam karya sastra dikaji menggunakan pendekatan mimetik.

Menurut Abrams (dalam Ratna, 2011:70), pendekatan mimetik merupakan pendekatan estetis yang paling primitif. Akar sejarahnya terkandung dalam pandangan Plato dan Aristoteles. Menurut Plato, dasar pertimbangannya adalah dunia pengalaman yaitu karya sastra itu sendiri tidak bisa mewakili kenyataan yang sesungguhnya, melainkan hanya sebagai peniruan. Secara hierarkis dengan demikian karya seni berada di bawah kenyataan. Pandangan ini ditolak oleh Aristoteles dengan argumentasi bahwa karya seni berusaha menyucikan jiwa manusia, sebagai katharsis. Di samping itu juga karya seni berusaha membangun dunianya sendiri.

Cerpen yang berjudul "Ibu Pergi ke Laut" karya Puthut EA merupakan cerpen yang ditulis berdasarkan kisah nyata yang terjadi pada tanggal 26 Desember 2004, yaitu musibah tsunami di Aceh dan sekitar wilayah sekitar Samudera Hinda. Kejadian tersebut merupakan musibah yang tidak pernah dilupakan oleh masyarakat Indonesia karena jumlah korban tewas mencapai 126.000 jiwa. Cerpen ini sangat cocok untuk ditelaah dengnan menggunakan kritik mimetik karena ceritanya berkisah dari kejaidan yang benar-benar terjadi dan merupakan cerminan nyata yang dialami oleh korban maupun kelurga yang ditinggalkan saat itu.

Pembelajaran bahasa Indonesia di Sekolah Dasar (SD) diarahkan untuk dapat berkomunikasi dengan baik, baik secara lisan dan tulisan, serta mampu menumbuhkan apresiasi terhadap hasil karya sastra. Oleh karena itu, pembelajaran bahasa
Indonesia di SD memuat pembelajaran sastra di dalamnya.

Pembelajaran apresiasi sastra di SD merupakan upaya penanaman rasa peka kepada siswa rasa cinta terhadap sastra. Seharusnya, pengajaran apresiasi sastra mampu mengubah sikap siswa dari acuh tak acuh menjadi lebih bersimpati terhadap sastra (Susanti, 2015: I36). Dengan demikian, karya sastra harus dipahami sebagai fenomena yang tidak hanya sekedar memuaskan emosi melainkan memercikkan ide-ide dan pikiran. Selain itu, Pembelajaran sastra penting bagi siswa karena berhubungan erat dengan keharuan. Sastra dapat menimbulkan rasa haru, keindahan, moral, keagamaan, khidmat terhadap Tuhan, dan cinta terhadap sastra bangsanya (Broto, 1982: 67).

Tarigan (I99I:I76) menyatakan bahwa cerita pendek adalah penyajian suatu keadaan tersendiri atau suatu kelompok keadaan yang memberikan kesan yang tunggal pada jiwa pembaca. Melalui cerpen, siswa SD mampu mempelajari dan memahami kisah-kisah teladan yang patut dijadikan contoh. Oleh karena itu, cerpen yang berjudul Ibu Pergi ke Laut dapat dijadikan siswa SD sebagai pembelajaran dari pengalaman orang lain untuk direfleksikan dalam mengahadapi masalah dalam kehidupan. Kompetensi dasar yang dapat sesuai dengan pembelajaran sastra melalui materi cerpen yaitu kelas IV yang berbunyi "Mengomunikasikan pendapat pribadi tentang isi buku sastra yang dipilih dan dibaca sendiri secara lisan dan tulis yang didukung dengan alasan”.

\section{Metode}

Metode penelitian dalam penelitian ini menggunakan metode deskriptif kualitatif.Strategi penelitian yang digunakan adalah studi kasus terperancang. Dalam penelitian ini studi kasus terperancangnya yaitu kritik sastra melalui pendekatan mimetik sosial pada cerpen Ibu Pergi ke Laut karya Puthut EA. Data dalam penelitian ini berupa kata-kata yang menggambarkan pendekatan mimetik. Teknik pengumpulan data dalam penelitian ini menggunakan teknik pustaka, simak dan catat. Pemilihan data cerita pendek Puthut EA menggunakan teknik purposive sampling. Purposive sampling adalah pengambilan sampel yang disesuaikan dengan tujuan penelitian (Siswantoro, 2010:73). Triangulasi yang digunakan yaitu teknik triangulasi teori. Teknik analisis data menggunakan teknik analisis dialektika.

\section{Hasil dan pembahasan}




\section{Analisis Kritik Mimetik Cerpen "Ibu Pergi Ke Laut" karya Puthut EA}

Cerpen "Ibu Pergi ke Laut" karya Puthut EA sayang untuk dilewatkan begitu saja tanpa dibaca. Kepandaian pengarang mengolah katakata menjadikan cerpen sangat menarik untuk dibaca oleh penikmat karya sastra. Sebagai cerpen yang bersumber dari kisah tsunami Aceh pada tanggal 26 Desember 2004, cerpen ini terasa menyayat hati pembaca karena pengarang berhasil memosisikan dirinya dengan baik sebagai anak kecil yang polos, yang tidak mengetahui fakta bahwa ibunya telah meninggal. Dia hanya tahu ibunya sedang pergi ke laut bersama ikan-ikan.

Sang ayah sangat menyayanginya, tidak mampu berkata dengan jujur mengenai kejadian yang sebenarnya. Hal ini pun juga dialami oleh kebayakan orang tua lain yang tidak mampu mengatakan fakta yang sebenarnya karena ketidaksiapan jiwa seorang anak balita untuk menerimanya. Gambaran ini bisa terlihat pada kutipan cerpen berikut.

Ayah bilang ibu pergi ke laut. Waktu aku tanya kenapa ibu tidak pulang, ayah menjawab, ibu mungkin tidak pulang. Tentu saja kemudian aku bertanya apakah ibu tidak kangen padaku? Dan ayah menjawab, tentu saja ibu kangen dan tetap sayang padaku. Tapi kenapa ia tidak pulang? Apakah ada seorang anak sepertiku yang ada di laut sehingga ibu tidak mau lagi pulang ke rumah ini? Sepasang mata ayah kemudian berair (Puthut EA, 2005:01).

Dalam kutipan cerpen di atas, Sang Ayah tidak mengatakan fakta bahwa istrinya telah meninggal karena menjadi salah satu korban tewas pada tragedi tsunami Aceh 2004. Ia justru mengatakan bahwa Sang Ibu sedang berada di laut. Jawaban polos Dinda, nama anak kecil tersebut, tidak disangka sama sekali oleh Sang Ayah sehingga membuatnya menitikkan air mata. Dan pengarang dengan lihai menggambarkan air mata sebagai sepasang mata yang berair dari sudut pandang anak kecil. Sangat terasa sekali kepedihan yang dialami oleh Sang Ayah sehingga pembaca pun juga turut larut dalam kepedihan tersebut.

Puthut EA mampu menangkap fenomena yang benar-benar terjadi dalam masyarakat Indonesia dan mengungkapkan-nya dengan sangat baik ketika ia menceritakan bahwa ketika ada seseorang yang mengalami musibah, semua orang pasti akan bersimpati. Hal tersebut dapat dilihat pada kutipan cerpen di bawah ini.

Semua orang tiba-tiba terlihat semakin sayang sama aku. Tetangga-tetanggaku, tante-tanteku, semua terlihat semakin sayang. Nenek dan kakekku bahkan perlu tinggal berminggu-minggu di rumahku setelah ibu pergi ke laut. Bergantian mereka mengelus-elus rambut dan memelukku, apalagi ketika menonton televisi. Di televisi, aku melihat banyak bangunan yang rusak. Aku melihat air yang berlimpah menghanyutkan banyak orang dan barang. Aku senang sekali dengan air. Aku bertanya dari mana air sebanyak itu? Nenek bilang air itu datang dari laut. Lalu aku teringat ibu. Bukankah ibu ada di laut? Nenek dan kakekku lalu terdiam. Mata mereka berair (Puthut EA, 2005:01).

Gambaran di atas mencerminkan kehidupan masyarakat yang akan semakin memperhatikan keluarga korban, terutama kepada anak yang ditinggal pergi oleh orang tuanya. Bahkan, kakek nenek yang harus menginap di rumah untuk menemani pun juga sama persis dengan yang dialami oleh masyarakat Indonesia bahwa semua kerabat akan menginap ketika ada salah satu keluarga yang meninggal. Dengan sudut pandang kecil yang masih mengira bahwa ibunya masih berada di laut untuk menyelamatkan kapal yang tenggelam, semua orang merasa terenyuh dan tetap tidak mengatakan bahwa ibunya sudah pergi untuk selama-lamanya.

Puthut EA memaparkan dengan sangat baik hubungan antara ibu dan anak sehingga kerinduan anak kepada ibu tidak dapat dibendung karena halhal kecil yang selalu mereka lakukan bersama-sama. Setiap ibu dan anak akan memiliki kekuatan yang sangat erat yang tidak dapat dipisahkan, sama dengan yang terjadi dalam masyarakat bahwa anak akan sangat dekat dengan ibunya. Gambaran ini dapat dilihat dari kutipan cerpen di bawah ini.

Sebetulnya aku sangat rindu pada ibu. Aku rindu cerita-ceritanya, aku rindu diajak pergi ke kolam renang, aku pengin dibuatkan kue-kue yang enak. Tapi kalau kemudian aku ingat bahwa ibu harus memimpin ikan-ikan yang baik hati, aku hanya bisa diam. Pasti ibu kasihan melihat kapal-kapal yang akan tenggelam. Di dalam kapal-kapal itu pasti banyak anak kecil seusiaku yang belum bisa berenang. Ya, ibu harus menyelamatkan mereka. (Puthut EA, 2005:02).

Kutipan cerpen di atas menunjukkan bahwa dari sudut pandang anak kecil, hal-hal kecil seperti bersama-sama melakukan sesuatu dalam lingkup keluarga dan memberikan kasih sayangkepada anak melalui cerita dan makanan akan selalu diidamkan oleh seorang anak yang memiliki ibu. Cerpen ini 
mengajarkan hal positif bahwa sudah seharusnya orang tua memberikan kasih sayang kepada anaknya karena hal itu akan selalu diingat anak sampai kapan pun.

Cerpen ini sangat bermanfaat untuk menambah pengetahuan pembaca tentang proses terjadinya hujan. Tokoh Dinda yang ingin berkirim surat dengan ibunya yang berada di laut dan ia sadar bahwa tidak mungkin menggunakan jasa pos untuk memenuhi keinginannya tersebut. Gambaran tersebut dapat disaksikan pada kutipan cerpen di bawah ini.

Mbak Memi diam. Kemudian ia menjawab, "Lewat hujan, Dinda."

"Kenapa lewat hujan?"

"Kata bu guru, hujan itu berasal dari air yang menguap. Air di laut, di danau, di sungai menguap karena panas matahari. Uap itu lalu berkumpul menjadi awan, dan kemudian turun menjadi hujan."

Aku bingung. Tapi itu tidak penting. "Lalu surat dari ibuku ikut turun bersama hujan, ya?" (Puthut EA, 2005:04).

Materi tentang terjadinya hujan tentu saja telah dipelajari oleh semua orang yang telah menempuh pendidikan sekolah dasar. Namun, tidak banyak orang yang mengingatnya sehingga ketika diuraikan tentang proses pengiriman surat lewat sungai dan akan dibalas melalui hujan dengan teori yang sama dengan proses terjadinya hujan, pembaca akan langsung tersenyum dan berpikir betapa pintarnya pengarang menyajikan ilustrasi ringan yang sebelumnya tidak pernah terpikirkan oleh orang lain.

Ketabahan tokoh Ayah dalam menghadapi musibah kehilangan istri tercinta menjadi cerminan korban-korban bencana lain yang harus kehilangan sanak keluarga tanpa diduga sebelumnya. Jika tidak kuat menahan cobaan, hal ini akan berdampak buruk bagi keluarga korban yang ditinggalkan. Namun, Puthut EA mengemas ketabahan hati tokoh Ayah dengan sangat lihai sehingga membuat pembaca merasa kagum terhadap tokoh ciptaannya. Dan penggambaran dari sudut pandang anak kecil membuat cerpen ini tidak seperti menggurui pembaca. Kutipan suasana ketabahan hati tokoh Ayah dapat dilihat dari kutipan cerpen di bawah ini.

Aku terjaga ketika wajahku terasa basah. Aku hanya bermimpi. Aku merasa ayahku sedang menciumi wajahku. Samar kudengar ia berkata, "Maya... kamu tahu aku dan Dinda tidak pernah baik- baik saja tanpa kamu...." Lalu kurasakan suara ayah beralih menjadi suara tangis. Air matanya jatuh ke wajahku. Ia mengelap wajahku dengan rasa sayang. Aku tetap terdiam tanpa membuka mata. Tempat tidurku terguncang hebat. Tangis ayah terasa semakin kencang, dan lamat pula aku mendengat, "Maya, apa yang harus kukatakan kepada Dinda?"(Puthut EA, 2005:05).

Dari kutipan cerpen di atas, bisa dilihat kepedihan hati tokoh yang disembunyikan dari anaknya yang belum mengerti tentang yang sebenarnya terjadi. Kepandaian Puthut EA dalam meramu kata dari sudut pandang anak kecil mampu mengaduk emosi pembaca hingga ikut terbawa dalam emosi tokoh dalam cerpen tersebut. Apa yang dialami tokoh Ayah ini tidak jauh dari apa yang dialami oleh keluarga yang ditinggalkan oleh korban bencana yang masih memiliki anak kecil di keluarganya.

Sekali lagi, Puthut EA mampu menyuguhkan dengan sangat baik suasana haru yang dibalut dengan dialog antara ayah dan anak yang memiliki posisi sama, yaitu sebagai keluarga yang ditinggalkan oleh orang tercinta karena bencana alam. Kecintaan tokoh Dinda kepada ibunya dan ketidaktahuan tentang fakta yang terjadi pada ibunya membuat Sang Ayah senantiasa menangis tanpa diketahui penyebabnya oleh Dinda. Di bawah ini adalah kutipan dialog pamungkas dari cerpen "Ibu Pergi ke Laut" karya Puthut EA yang membuat pembaca tidak henti-hentinya teraduk emosinya meskipun hampir selesai membacanya.

"Dinda mau makan ikan apa?"

Aku menggelengkan kepala. Ayah heran, kemudian ia bertanya, "Kenapa, Dinda?"

"Kasihan ibu kalau ikan-ikan diambil terus. Nanti ibu kehilangan banyak teman di laut."

Kulihat ayah diam. Matanya berair. Ia menangis sambil memelukku. Aku heran sekali. Ayah sekarang gampang menangis! (Puthut EA, 2005:06).

Kenyataan bahwa banyak sekali kelurga korban bencana tsunami yang mengalami kejadian yang sama dengan para tokoh dalam cerpen "Ibu Pergi ke Laut" karya Puthut EA membuat pembaca digiring untuk memahami kesedihan yang dialami oleh "mereka". Di Indonesia tidak sekali atau dua kali saja terjadi bencana alam sehingga apa yang diceritakan pada cerpen ini sering terulang meskipun dalam bencana yang berbeda jenisnya. Indonesia berada di kawasan rawan bencana sehingga masyarakat harus senantiasa waspada dan tetap berempati terhadap korban ataupun keluarga setiap ada bencana yang terjadi karena tidak mudah menghadi setiap musibah yang datang tanpa diduga sebelumnya.

Meskipun cerpen ini sangat bermuatan hal positif baik dari segi nilai intrinsik maupun nilai ekstrinsik, ada satu hal yang kurang sesuai jika diterapkan pada kehidupan nyata. Seorang anak yang memiliki usia lebih tua justru seakan dibimbing oleh 
anak yang memiliki usia lebih muda. Hal ini dapat kita saksikan pada kutipan berikut.

Mbak Memi mengeluarkan sepeda mininya. Ia kemudian menemui Bi Nah untuk meminta izin pergi bersamaku naik sepeda. Dengan membawa kapal kertas yang berisi suratku, aku membonceng Mbak Memi menuju sungai. (Puthut EA, 2005:04).

Meskipun sepeda yang dipakai adalah sepeda milikDinda, sudah seharusnya tetap Mbak Memi yang membonceng Dinda sebagai bentuk kasih sayang dari yang tua ke yang muda. Terlepas dari hal ini, keseluruhan isi dari cerpen ini sangat layak untuk dijadikan sebagai cerpen yang memiliki mutu sangat bagus.

\section{Pembelajaran Sastra di Sekolah Dasar}

Di tingkat Sekolah Dasar (SD), pembelajaran sastra diarahkan kepada siswa dalam kompetensi mengenai apresiasi sastra.

Tujuan pembelajaran sastra di SD difokuskan untuk memahami dan mengapresiasi nilai-nilai yang ada di dalam karya sastra (Rusyana, I984:3I3). Pengetahuan atau teori tentang sastra bisa diakatakan hanya sebagai penunjang dalam mengapresiasi.

Proses pembelajaran apresiasi sastra di $\mathrm{SD}$, guru berperan dalam hal membacakan karya sastra secara ekspresif, yaitu membaca karya sastra dengan mengekspresikan isi dan makna, sedangkan siswa membaca secara impresif, yaitu membaca dengan menangkap maksud pengarang melalu imajinasinya atau makna karya sastra (Priyatni, 2010: 25). Oleh karena itu,cerpen Ibu Pergi ke Laut apabila diajarkan dalam pembelajaran sastra memerlukan peran serta guru dan siswa agar makna dalam isi cerpen tersampaikan serta tujuan pembelajaran dapat tercapai.

Membaca sastra anak berbentuk cerpen dengan Ibu Pergi ke Laut harus dirasakan para siswa, seperti mereka bermain dengan hati yang senang penuh kenikmatan. Oleh karena itu, tugas guru wajib memberikan motivasi dan arahan sebelum siswa membaca cerpen. Dengan demikian, apabila siswa membaca cerpen seperti masuk ke dunia bermain, dunia mereka penuh dengan keceriaan. Semakin banyak membaca karya sastra, makan semakin banyak pula kegembiraan yang mereka peroleh.
Anak-anak yang masih duduk di bangku sekolah dasar, harus diajak mulai mengembangkan kesadaran dalam bersastra. Tidak dapat dipungkiri bahwa pemahaman literer dapat meningkatkan kenikmatan anak terhadap suatu bacaan (Huck, 1987).

Setelah siswa membaca cerpen, siswa diminta mengintepretasikan mengenai cerita sesuai dengan KD yang dipilih, yaitu "Mengomunikasikan pendapat pribadi tentang isi buku sastra yang dipilih dan dibaca sendiri secara lisan dan tulis yang didukung dengan alasan". Cara siswa menginterpretasikan bacaan cerpen dengan mengidentifikasi para pelaku yang ada dalam cerita. Para pelaku dalam cerita dapat diperagakan atau didramatisasikan oleh siswa. Kegiatan tersebut memberikan manfaat dalam melatih cara mereka bersosialisasi. Selain itu, cara mengintepretasi yang lain yaitu melalui menulis essay, jurnal, atau surat yang berhubungan dengan tokoh cerita. Segala aktivitas tersebut dapat menambah interpretasi siswa terhadap cerita dan memperdalam tanggapan mereka pada bacaan.

Norton (dalam Nazurti, 2017: 40) menyatakan bahwa sastra anak merupakan cerminan perasaan dan pengalaman dari anakanak yang dapat dilihat serta dipahami melalui mata anak-anak. Karya sastra anak tidak hanya karya yang diciptakan oleh anak-anak, tetapi siapapun boleh berkarya. Boleh saja karya orang dewasa, tetapi berisikan cerita yang mencerminkan perasaan dan pengalaman anakanak, serta mampu dinikmati oleh anak-anak sesuai pengetahuan mereka. Maka dari itu, cerpen Ibu Pergi ke Laut merupakan karya sastra yang cocok dan harus disediakan sebagai bahan pembelajaran sastra di Sekolah Dasar.

\section{Simpulan}

Cerpen "Ibu Pergi ke Laut" karya Puthut EA merupakan cerpen yang mencerminkan kenyataan pada masyarakat korban bencana yang terjadi di Indonesia sehingga sangat tepat apabila dikaji dengan menggunakan pendekatan kritik mimetik. Dikemas dengan sudut pandang anak kecil yang polos, cerpen ini mampu menggugah emosi pembaca secara berulang-ulang karena kata demi kata yang disajikan pengarang benar-benar tersusun dengan sangat menarik dan tidak pernah terpikirkan sebelumnya bagi pembaca. Sikap para tokoh untuk menutupi 
luka hati karena kehilangan orang yang dicintai dalam musibah bencana tsunami Aceh 2004 dengan berpura-pura tidak terjadi apa-apa di depan anak kecil yang masih polos justru menjadi kekuatan pada cerpen ini.

Melalui pembacaan karya sastra, seperti cerpen Ibu Pergi ke Laut, kemampuan siswa dalam berkomunikasi secara lisan dan tulisan juga akan turut terkembangkan. Hal tersebut terjadi karena siswa banyak memahami kosa kata dari yang telah dibacanya, baik dari gaya bahasa, atau kalimatkalimat. Kepekaan siswa pada cerita juga akan terlatih dan pada akhirnya mereka menjadi peka pada kehidupan sehari-harinya. Tokoh-tokoh dalam cerpen Ibu Pergi ke Laut secara tidak sadar akan membuat siswa mampu mengendalikan berbagai emosi.

\section{Persantunan}

Artikel ini disusun atas dorongan dan dukungan dari berbagai pihak. Ucapan terimakasih disampaikan kepada PGSD FKIP Universitas PGRI Madiun dan teman-teman sejawat. Ucapan terima kasih juga disampaikan kepada tim editorial Bahastra Pendidikan Bahasa dan Sastra Indonesia Universitas Ahmad Dahlan yang telah memberikan ruang untuk penerbitan artikel ini. Semoga artikel ini dapat memberikan kontribusi dalam pembelajaran terutama dalam kegiatan literasi kritis.

\section{Daftar Pustaka}

Bower, G. H. \& Hilgard, E. R. I98I. Theories of Learning. Englewood Cliffs New Jersey: Prentice Hall.

Fajarini, Ulfah. 20I4. Peranan Kearifan Lokal dalam Pendidikan Karakter. Jurnal Sosio Didaktika Vol. I No. 2 Juni 2014.

Huck, Charlotte. dkk. 1987. Children Literature in the Elementary School. Chicago: Rand McNally College Publishing Company.

Nazurti. 2017. Studi Kasus Pembelajaran Apresiasi Prosa Di Kelas V SD Negeri I5/IV Jelutung Kota Jambi. Jurnal Pendidikan Tematik Dikdas. Vol. 2 No.I Oktober 2017.

Priyatni, Endah Tri. 20I0. Membaca Sastra dengan Ancangan Literasi Kritis. Jakarta: Bumi Aksara.

Rahayu. 20I4. Analisis Bumi Manusia Karya Pramoedya Ananta Toer Dengan Pendekatan Mimetik. Deiksis: Jurnal Pendidikan Bahasa dan Sastra Indonesia. Vol. I No.I Juli 2014.

Rahyono. F.X. (2009). Kearifan budaya dalam kata. Jakarta: Wedatama Widyasastra.
Rusyana, Yus. 1984. Bahasa dan Sastra dalam Gamitan Pendidikan. Bandung:CV. Diponegoro.

Siswantoro. 2005. Metode Penelitian Sastra: Analisis Psikologi. Surakarta: Muhammadiyah University Press.

Suastra, I.W. 2005. "Mengembangkan Pendidikan Berbasis Budaya Lokal di Sekolah. Jurnal Pendidikan dan Pengajaran” Jurnal Pendidikan, Volume 38, (3).

Sugeng. 2005. Bahasa dan Sastra Indonesia Kelas VII $S M P$ dan MTs. Jakarta : Bumi Aksara.

Sumayana, Yena. 2017. Pembelajaran Sastra di Sekolah Dasar Berbasis Kearifan Lokal (Cerita Rakyat). Mimbar Sekolah Dasar. Vol 4 (I) 2017.

Yunus, Risaid. 2014. Nilai-nilai Kearifan Lokal (Local Genius) sebagai Penguat Karakter Bangsa: Studi Empiris Tentang Huyula. Yogyakarta: Deepublish. 